\title{
Psychological Distress Experienced by Nurses who Work with Patients in Death Process: A Clinical-Qualitative Study
}

\author{
Rodrigo Almeida Bastos ${ }^{1, *}$ \\ Orcid.org/0000-0002-6159-8048 \\ Alberto Manuel Quintana ${ }^{2}$ \\ Orcid.org/0000-0001-7356-6142 \\ Franco Carnevale ${ }^{3}$ \\ Orcid.org/0000-0001-7255-9979
}

\author{
${ }^{1}$ Universidade Estadual de Campinas, Campinas, SP, Brasil \\ ${ }^{2}$ Universidade Federal de Santa Maria, Santa Maria, RS, Brasil \\ ${ }^{3}$ Universidade McGill, Montreal, Canadá
}

\begin{abstract}
This research aimed to know the anguish experienced by nurses who work with patients in risk or in dying process in a hematology-oncology unit. A clinical-qualitative study, conducted through individual interviews. The participants were 06 nurses from hematology-oncology unit of a university hospital. The results were grouped into five categories, which refer to the loss of professional autonomy when the nurse is faced with the difficulty of thinking about their own work. Working with children affected by cancer seems to be a symbol of greater anxiety in dealing with death. While that, the improvement or cure of hope brings motivation to nurse, the death of the child patient has the meaning of helplessness, sadness and hopelessness. Nurses throughout the work process have insights about how their relationship to work could be improved, but the nurses' concern has not been heard during the suffering. These findings emphasize the need for health care organizations, teams and even the nurses perceive this professional as an ethical subject, who needs to reflect their work to be able to plan some way to digest the anguish of working.
\end{abstract}

Keywords: Attitude to death, Nursing, Health Psychology, psychological stress.

\section{Angústias Psicológicas Vivenciadas por Enfermeiros no Trabalho com Pacientes em Processo de Morte: Estudo Clínico-Qualitativo}

\section{Resumo}

Esta pesquisa objetivou conhecer as angústias vivenciadas pelos enfermeiros no trabalho com pacientes em risco ou em processo de morte em uma unidade hemato-oncológica. Estudo clínico-qualitativo,

* Mailing address: Universidade Estadual de Campinas, Departamento de Psicologia Médica e Psiquiatria, Prédio FCM1 1, $3^{\circ}$ andar, Rua Tessália Vieira de Camargo, 126, Cidade Universitária Zeferino Vaz, Campinas, SP, Brazil 13083-887. Phone: (75) 9 9210-8559.E-mail: almeidabastos.rodrigo@gmai.com

Agradecimento: Agradecimento à Fundação de Amparo à Pesquisa do Estado do Rio Grande do Sul, a qual financiou esta pesquisa ao longo de dois anos. 
realizado por meio de entrevistas individuais. Participaram desta pesquisa 06 enfermeiros da unidade hemato-oncológica de um hospital universitário. Os resultados foram reunidos em cinco categorias, as quais remetem à perda da autonomia profissional quando o enfermeiro se depara com a dificuldade de pensar o seu próprio trabalho. O trabalho com a criança com câncer parece ser símbolo de uma angústia maior em lidar com a morte. Ao mesmo tempo em que a melhora ou a esperança de cura dá motivação ao enfermeiro, a morte do paciente infantil tem o significado de impotência, tristeza e desesperança. Os enfermeiros, ao longo do processo de trabalho, têm insights sobre como a sua relação com o trabalho poderia ser melhorada, porém, no momento do sofrimento, a preocupação dos enfermeiros não foi ouvida. Há a necessidade de que instituições de saúde, equipes e o próprio enfermeiro percebam esse profissional como um sujeito ético, necessitando refletir seu trabalho para que haja possibilidade de planejar alguma forma de digerir a angústia do trabalho.

Palavras-chave: Atitude frente à morte, Enfermagem, Psicologia da Saúde, estresse psicológico.

\section{Angustia de Enfermeras en Trabajo con Pacientes en Proceso de la Muerte: Estudio Clínico-Cualitativo}

\section{Resumen}

Este estudio tuvo como objetivo conocer las angustias experimentado por enfermeros que trabajan con pacientes en riesgo o proceso de morir en una unidad de hemato-oncología. Estudio clínicocualitativo, realizado a través de entrevistas individuales. Los participantes fueron 06 enfermeras de la unidad hemato-oncológica. Los resultados demuestran la pérdida de la autonomía profesional cuando la enfermera se enfrenta a la dificultad de pensar sobre su propio trabajo. El trabajo con niños con cáncer parece ser un símbolo de mayor ansiedad para hacer frente a la muerte. La mejoría o curación de la esperanza motivación para la enfermera, la muerte del paciente infantil tiene el significado de impotencia, tristeza y desesperanza. Enfermeras, a lo largo del proceso laboral, tienen ideas sobre cómo se podría mejorar su relación con el trabajo, pero la preocupación de las enfermeras no se han escuchado durante el sufrimiento. Existe la necesidad de que las instituciones de salud, equipos e incluso las enfermeras perciben este profesional como sujeto que requiere reflejan su trabajo de modo que no hay posibilidad de planificar alguna manera de digerir la angustia de trabajo.

Keywords: Actitud frente a la muerte, Enfermería, Psicología de la Salud, Estrés Psicológico, Psicología.

Throughout history, distinct sociocultural contexts have shaped the idea man has of death. This dynamic idea even has the power to transform the ways of life of a society, making the meaning of death and dying an interesting reflection of the meaning of life itself for this society or for the subject that composes it. From the wide open death in the Middle Ages to the forbidden death in modern times, what is perceived is that there has always been fear when faced with this phenomenon. This fear translates into anxieties experienced by people related to their lack of control over death and its signs (Ariès, 2003).
Caring for those facing death is therefore a challenge particular to the contemporary paradigm. What was previously a family function becomes the responsibility of health professionals, saturated in science and techniques, theoretically sufficient for work with patients at risk or in the death process (Ariès, 2003; Souza e Souza et al., 2013). However, people's lives are not merely science and techniques. Health professionals are, above all, subjects integrated into a political-social paradigm, in which death must be avoided and life saved at all costs (Borges \& Mendes, 2012). This is how the history of the anguish of these professionals, in the context of death, has its genesis. 
The nurse fits into this process of anguish in the care of others as an active character. The experience of this professional in the hospital environment, where death lurks close by, is characterized by a direct battle between the life and death of the patients. As an aggravating factor, nurses are, in this context, directly responsible for managing the integral care of all patients in the unit. Their training is characterized by demands and a firm posture, with them, often, prevented from expressing what they really feel about the work (Santos \& Bueno, 2010).

Throughout their experiences, nurses often have to deal with the situation of the death of patients under their care. The difficulties encountered in these cases are mostly related to the professionals' own difficulty in perceiving death as an integral part of life, reflecting in each case their own anguish about the theme. The constant coexistence with situations of death does not exempt these professionals from the expression of feelings of anguish and suffering, with it being necessary to understand these experiences in order to perceive what this contact means for the nurse (Souza e Souza et al., 2013). The need for this understanding goes beyond the desire to improve nursing care. Understanding these experiences means giving a voice to this caregiver, who is usually silent in the face of the anguish of caring for the pain of others. Speaking about distressing experiences makes the subjects reflective toward their practice, with the healthcare process benefiting as a consequence of the improvement of the nurses as subjects.

Considering this context, however, favoring the investigation of the reflections of the research subjects, this article aims to present the results of interviews regarding the anxieties experienced by nurses in working with patients at risk or in the process of death, in a hematooncological unit. The hemato-oncological sector was a revealing field of study regarding these experiences, as it is a long-term therapeutic environment that is demanding in terms of technical-scientific knowledge. Hemato-oncological care exposes the professional to social and emotional relationships with the subjects involved in the treatment. The work process in this area exposes the caregivers to a reflection about their own practice, as well as about life itself (Umann, Silva, Benavente, \& Guido, 2014).

\section{Method}

This was a clinical-qualitative study, having the meanings and significations of the phenomena as the basis for the research and for the researcher (Turato, 2013). The study was performed in the hemato-oncology clinic of a university hospital in the state of Rio Grande do Sul, Brazil, during the year 2015. The hemato-oncology clinic was chosen for the work of the study due to the particularity that exists in this unit regarding the relationship between the nurses, patients/family members and the caregiver team.

\section{Participants}

The study included 06 nurses from the chemotherapy outpatient and infant hospitalization sectors of the hemato-oncology unit of a university hospital. The hemato-oncological unit consists of four sectors, namely: Chemotherapy Outpatient Clinic, Infant Hospitalization, Adult Hospitalization and Bone Marrow Transplantation Center (CTMO). Only the professionals of the first two sectors were included in this study, based on criteria of availability or interest.

Among those interviewed there were 05 women and 01 man, aged between 30 and 50 years. The time since formation varied between 09 and 25 years and the length of professional experience in the hemato-oncological sector between 04 months and 20 years. The inclusion criteria were: carrying out professional activities with patients at risk or in the death process and agreeing to participate in the study by signing the consent form. The nurses on vacation, maternity leave, medical leave or away for academic improvement study, as well as those who were not interested in participating in the study were excluded.

\section{Instruments}

Information was collected through individual interviews, based on a semi-structured script. The strategy used to identify the number 
of participants was theoretical saturation (Turato, 2013). The interview script, common to all, addressed aspects of quality of life and work with patients at risk or in the death process. This script has the function of delimiting the indispensable questions for the research during the interview, guiding the researcher to stimulate the interviewee's speech about the themes (Minayo, 2010). In the case of this study, it guided the comprehension of the self-care experiences of the nurses, whose work involves, among other things, the approximation with the moment or process of death of the patients hospitalized in the hemato-oncology unit.

\section{Data Collection Procedures}

In order for the collection to be started, a copy of the research project was sent to the target institution of the study. Having been judged relevant by the people responsible, it was submitted to the evaluation of the Research Ethics Committee (CEP). After receiving authorization by the CEP, the first contact was made with the unit for the invitation of the participants. The information gathering phase occurred from July 2015 to November 2015. Using the research instrument, an interview of acculturation was conducted, the purpose of which was, according to Turato (2013), "to enable the researcher to experience his/her process of assimilation of the way of thinking of that target population, in whose environment he/she will be temporarily immersed" (p. 316).

\section{Ethical Procedures}

The study was based on Resolution 466/2012 of the National Health Council, which regulates research with human subjects. The field activities occurred after approval by the Research Ethics Committee of the institution where the study was carried out, and the project was approved under CAAE number 40608715.9.0000.5346. In order to preserve the anonymity of the participants, the statements that illustrate the categories were coded, as follows: E (Nurse), followed by a number between 1 and 6 , as well as the length of experience in the hemato-oncology service, in the range format.

\section{Results and Discussion}

From the analysis of the information collected during the interviews, some categories emerged that referred to the difficulties experienced by nurses working in the context of death in hemato-oncology. The categories are presented and discussed below, in order to perceive the correlation between the various anxieties experienced by the nurses, considering the diverse factors that permeate their work with patients at risk or in the death process.

\section{Beyond the Arch: The Quality of Life is Outside Work}

The reports of the participants refer to the quality of life as a result of experiences outside the work environment. This "Arch", as a physical structure present on the route of access to the hospital space, symbolizes for the local nurses the point of entering and leaving the work environment. The reports suggest that there is difficulty in reflecting on the moments that interfere in the quality of life itself. The desire is to find outside the work space the moments of satisfaction and tranquility that the hospital does not contemplate. The quality of life is a subjective and multidimensional construct, being experienced in an individual way by the subjects, by triggering their subjectivity, their relationship with themselves (Colomé \& Oliveira, 2012).

And so, you think about having leisure time, of doing things outside the work environment... so I think it's something we should think about more, but we stop to think about it when someone comes and asks... like here at this moment. (E3, between 05 and 10 years in the service)

In the hospital work, the subjectivity of nurses is subject to different demands through the type of work performed, with life and death as sources of challenging reflection in their practice (Borges \& Mendes, 2012). If the work with death causes discomfort, aggression and weight in the daily routine, the testimony suggests that the quality of life, meaning peace of mind and tranquility, is located outside the work environment. 
We are in a place so... heavy with... with... So much physically, that we see situations... [sighs]... true aberrations, of anatomical issues, tumors and everything... and that hurts... To have tranquility, peace of mind. This is quality of life for me. (E1, between 05 and 10 years in the service)

The meaning of work as an anguish factor for the interviewees can be understood as a consequence of the hospital institutional philosophy and the type of work performed. Hospitals generally seek care and management models in order to achieve results that optimize resources and ensure improvements in the service provided. This institutional thinking limits the participation of the healthcare worker in discussions about the improvement of the services, because it is this worker who must adapt to the institution and not the other way around. This context leads to a low association, for the worker, between the work process and quality of life, causing this subject to look outside the work environment for the resources for satisfaction with life (Tschiedel \& Monteiro, 2013). The result generates conflicts and psychic attrition in this professional, even compromising the capacity to think about self-care.

"I think that nowadays I can have a little more [quality of life]. But I think sometimes the institution could provide some things that would help more. I think they should have things here inside the hospital" (E3, between 05 and 10 years in the service).

It is no wonder that the type of work performed by hemato-oncology nurses has such a potential to distress them and provoke this psychic fatigue. A particularity of this service is the constant tension due to waiting for the occurrence of what is so frequent unwanted: death.

\section{I do Not Know How I Cope: The Occurrence of Death as a Factor of Professional Anguish}

The occurrence of death: the peak of the anguish of the professional who works with the bond and with the affections resulting from the relationship with the patient. Among the reports, a dilemma arises and is answered soon after.
Does professional maturity lead to better work or make the professional more insensitive to the occurrence of death? The statements suggest that, at the beginning of the professional life, the nurse still has the opportunity to use strategies to elaborate the loss of a patient, however, over time, living with death situations seems to make the elaboration process of mourning of the professionals more rigid, making them insensitive as a defense mechanism. It is important to realize that the sensitivity to the verbal and non-verbal manifestations of the patient is an important tool in identifying the unique needs of each one (Peterson \& Carvalho, 2011). However, perceiving the imperceptible and dealing with the mobilizations that this perception generates in the nurse becomes a source of anguish that cannot always be elaborated.

And then... then there was so much death that... I do not know... I do not know if you get used to it or if you work better... And I remember that I always said [to the family members]: "Talk... talk to him... Talk to him, play. Say you love him, ask forgiveness". I remember, therefore, that I dealt [formerly working in the ICU] better with these questions. (E1, between 05 and 10 years in the service)

The frequent coexistence with the death of patients does not exempt the professionals from the mobilization of feelings of anguish, however, on the contrary, from this anguish must arise a re-signification of death and of the life itself of the professional. However, supports are necessary for there to be means for re-signification of this suffering, otherwise helplessness and sadness are generated from the loss of control over life (Sanches \& Carvalho, 2009; Souza e Souza et al., 2013).

Feeling sad, you know... and feeling helpless, that there is nothing you can do. That you are there and are unable to do anything... and he was taking medications, painkillers, direct morphine, dipyrone, everything you could imagine for pain and it didn't help. I do not know how I cope... I think that... it is the time that goes by... that passes, you know... that weakens that feel- 
ing. That thought... (E4, up to 01 year in the service)

Nurses are, therefore, actors in a cycle of professional anguish, since their training does not contemplate coping with the death of their patients, reducing their arsenal of elaboration strategies and making them psychically vulnerable in the field of practice (Souza e Souza et al., 2013). This field, in the figure of the hospital institution, requires work that prioritizes productivity and rationality in the care, restricting the moments of reflection regarding the professional practice, the limitations of the professionals and their desires as human beings, whose job is to take care of others on their deathbeds.

You have to... You have to be well because who is going to get bad will be ... the family. If you get bad too, how can you help, right? So I think that even if you are crying inside, you have to at least show some calm to the person who will be there in front of you, to the mother who is crying. Imagine if you cried together with the mother? You have to look a little stronger in front of the familiar. (E4, up to 01 year in the service)

The consequence of this ethical incompatibility, perceived in the statements of the interviewees, is the suffering expressed through insensitivity to the context of death and the emergence of a new anguish: that of perceiving a degree of psychic toxicity through the bond created.

\section{Prefer to Withdraw: The Hostile Bond}

Even though the perception about the distress of patients or family members is impaired, the intention is to postpone or discard the idea of the bond and to try not to suffer. It is important to note that this phenomenon described in the following statements suggests a degree of declassification of the work of the nurses. The nurses take care of the biological and subjective requirements of the subjects, needing to regularly calibrate their capacity to perceive the issues evidenced or unspoken by patients and their families. Giving up this ability in their work can be thought of as a type of depersonalization, that is, the nurses cease to actively participate in the working life, becoming passive, performing activities almost automatically, like being strangers to themselves.

Sometimes I even try to keep myself a bit more distant, right. To not feel the blow so much. Because, for example, there are colleagues who... who know about the life of the family, who know them, who know the life history, right... I try not to go too deep. I think that suddenly you suffer less or perceive this less. (E4, up to 01 year in the service)

Vieira and Marques (2012) reflect that the healthcare team does not usually use the tool of listening in the context of death or suffering because this refers to a feeling of helplessness faced with not knowing. In this way, it is possible that the feeling of helplessness on behalf of a healthcare professional, faced with the death of a patient, arises from talking and listening to the other, because it refers to the lack of answers about what will happen. Listening starts to have, unconsciously, a toxic character for the nurse.

Health professionals, when thinking of themselves as subjects of supposed knowledge, are frustrated to realize in their practice that they do not know everything. This idea of supposed knowledge has its origin in health education focused on biological issues, as well as in the hospital institutional philosophy and society culture in which the professionals are part. This social culture guides individuals to be submissive to the knowledge of the health professionals, subjectively causing these professionals to position themselves as the bearers of knowledge. Finally, the health professional, believing this idea of supposed knowledge, exerts the power in the relationship with the patient. (Foucault, 2010; Gimenes, 2013).

We do not ask, but they make a point of telling us some things. So you end up creating a bond... That's why it's a bit difficult to work here. Because emotionally you end up not wanting it... you end up getting involved with them. (E6, between 15 and 20 years in the service)

In fact, to listen to the patient/family should be developed and stimulated through the team. 
However, it seems to be necessary to better understand the difficulty or denial of this listening by the nursing professionals, since it seems to be a psychic protection against the burden of anxiety that the nurses receive when they come into contact with the suffering of others. Hence the importance of the multidisciplinary team in supporting the technical and subjective deficiencies of the team itself. It seems from the statements that follow, the burden of anguish is especially produced when working with children with cancer.

\section{Why a Child?: The Symbol of the Child With Cancer}

The abrupt occurrence of a child's death becomes potentially damaging to the nurse's psyche due to the constant variation of conflicting feelings, between the comfort of smiles in moments of therapeutic stability and the frustration with the worsening clinical condition and the occurrence of death (Santos, Jesus, \& Portela, 2013). In a biopolitical assessment, the comfort of the child's smiles and the hope of a probable cure for a clinically terminally ill patient are traced back to the difficulty of accepting death by the health professional, trained to save lives at any cost. The relationship between power over life and acceptance of death by the nurse is of invasion or violation of this supposed power (Pelbart, 2008). The death of the child seems to have an even more distressing difference when perceiving this violation of the control over life.

So I guess it's... the chronological order that we expect to happen. So death in a child I think reverses this period that we consider normal. So that's why I think a lot of people see this as much more suffering, right? More emotional... (E3, between 05 and 10 years in the service)

Relationships of power naturally exist in the life of the subjects, influencing the view of the body and mind. Healthcare professionals use the natural sciences as a tool of power in this relationship, defining how the subjects perceive, feel, and think about life and death. The old power of death as a symbol of sovereign power, when to make someone die was a symbol of power, is recovered by the administration of bodies and the management of life, in which to make someone live becomes hegemonic. According to Pelbart (2008), the child or adolescent body is seen in this system of power over life as potentially productive, constructing a formation for the healthcare professionals based on this management of life. In this way, the clinical reasoning and personal actions of the healthcare professional consider the productive potential of the child, perceiving it in a natural cycle of life, aiming for a cure at any cost and making the professional ask at the moment of death: "why a child?".

While there's so many things happening here, why a child? Why an adolescent? We end up suffering a lot. It's amazing how such things are cyclical. Suddenly there is no one, no one is feeling ill. Soon it is a cycle of five, six dying and, you know... so it is... it is quite complicated and it makes an impression. (E2, between 15 and 20 years in the service)

Death out of place shows the total impotence in exercising control over it. In the midst of discourses of suffering prior to the death of children, some contradictions are not uncommon, precisely because the child has a consoling role in moments of stability or recovery (Poles $\&$ Bousso, 2006). However, when faced with the child's death, the nurse tends to recapture the suffering of loss of form, perhaps, more intensely. The "best contact . . of all", becomes "the worst of all" experiences.

$\mathrm{He}$ [the child] came and asked for me by my name. And that was the best contact I had of all. And then also, that day he... he became poorly, he got bad, then I ended up taking him to the ICU, right. ... So I guess this was the... worst of all... this was the child I had most contact with, you know? I got involved, like this... (E4, up to 01 year in the service) The conflicts faced by nurses in their practice with patients in the process of death should be accompanied by a support network, either through the initiative of the management or through the work team itself. When there is a 
lack of support for these moral conflicts, the professional starts to feel guilty, frustrated or impotent (Barlem et al., 2013). The discourses that follow suggest suffering in the moral dimension of the activity of the nurse.

\section{What is the Reason for Such Anguish? Hopelessness: Moral Suffering}

The anguish provoked in the moral dimension of the subject, called moral suffering, is due to the incoherence between the ethical and moral convictions of these subjects and their actions. In the practice, the subjects know what should be done according to their values, however perceive themselves as unable to act, either due to errors of judgment, personal failures or even circumstances beyond their personal control (Barlem, Lunardi, Lunardi, Dalmolin, \& Tomaschewski, 2012).

In the discourses that follow, it can be perceived that it is difficult to reflect on the best thing to do faced with so many rules and routines that govern the life of the professional. The nurse is led to act paying more attention to the rules and less like a caregiver. The result is a restrained patient, who swallows his fears, wrapped in hard technologies, and a professional or team that suffers due to the type of work and the impossibility of changing their routine.

Ah! But what is the cause of such anguish? Yes... the thing that most leaves me this way... hopelessness... it is that we could not change the situation. That... this impossibility of being able to change some things. What we saw, what was there, what was in front of us that we had to change. But we could not do it... change that reality. (E2, between 15 and 20 years in the service)

There is hopelessness and impotence faced with the care protocols. The professionals are led to act in partnership with the inconsistency of what they believe to be right at that moment. Over the years small situations increase the burden of anguish and suffering, because there is nowhere to go. The psychic damage becomes such that the ideations begin to have a character of mental illness (Barbosa, Vieira, Alves, \& Virgínio, 2012). Anguish and suffering need to come out in some way, even if it is through the extinction of one's own life.

To tell you frankly that if I did not mess up my life someday it was... because... I do not know why. But you know... we start to get frustrated with a lot of things . . . we go through very bad situations... so I went through this stressful time, of course I didn't... I didn't seek outside help... but I had to leave, I needed to stop a moment... (E2, between 15 and 20 years in the service) When working with the tensions of the context of death and with the impossibility of change it is very difficult to stop for a moment to think, to do the exercise of reflection. The literature clearly demonstrates the ideal that situations that generate moral suffering, such as a distressing work environment, ambiguous roles and lack of clarity regarding the tasks to be performed, have adverse effects on the mental health of healthcare professionals, especially nurses, who deal with the anguish of others (Barbosa et al., 2012; Manetti \& Marziale, 2007). These situations are potential generators of phenomena such as depression and suicidal ideation, considering the feelings of emptiness, loss of identity and difficulty in denominating the experiences.

The experiences of suffering reported are generated by situations where the nurses cannot act according to what is expected of them in their work with patients in the process of death. The tension generated can be so great that the fantasy of causing suffering appears, generating feelings of guilt and impotence in situations where there is no potential for negligence, recklessness or malpractice.

I was in a situation once, where I started suffering, but... it was not due to a death, it was because of a procedure, an administration of a chemical that I did and that overflowed. Then it injured the patient and I was left with that thing that it had been my fault . . I was left with that causing me such great suffering of responsibility for the patient... (E3, between 05 and 10 years in the service) Nurses are not free to shape the ethical standards of their own profession or to act au- 
tonomously, precisely because of sociopolitical issues (Carnevale, 2013) or power relations (Foucault, 2014). It is important that this moral complexity of the nursing practice be recognized so that the influence on the psychic health of the professional and the consequences for the care itself can be perceived (Carnevale, 2013).

It is noticeable throughout the discourses that the professionals, concomitant with describing their own suffering, resonated with selfreflections. They knew the reason for the anguish, described the ethical conflict to which they were inserted and of which, at that moment, they could not leave. There is the reflection, as seen in this last discourse, of a self-defense regarding the guilt that they had signified for themselves in that given situation. That is, the nurses had insights on how their care or how their relationship with the work could be improved. However, at the time of the suffering, the concern of the nurses was not heard. To give voice to the nurses, a space for the expression of feelings regarding the moral agency (Carnevale, 2013; Rodney et al., 2012), which involves their work, makes them realize that they are not alone in the arena of suffering faced with the context of death.

\section{Conclusion}

From the considerations developed in the discussion of the results, it was possible to highlight a series of psychic repercussions that go beyond the form of suffering, often silenced, according to the meanings attributed by the nurses to their experiences in the work with patient at risk or in the process of death. These repercussions seem to influence, not only the work process or the care provided, but also the meaning that work in the context of death assumes for the professionals.

The results highlight the loss of professional autonomy when the subjects are faced with the difficulty of thinking about their own work. This moral conflict negatively affects their perception of quality of life in the workplace and the relationship with the patient and family. There is a significant sense of anguish related to the type of work in the context of death, where, in addition to having to deal with the care for the pain of others, they have to face their own pain.

Given this reality, there is an obvious need for health institutions, teams and the nurses themselves to perceive these professionals as ethical subjects, who need to reflect on their work so that there is the possibility to plan some way to digest the anguish of the work. There is a need to create listening spaces for this caregiver subject, considering that, through speech, moments of reflection and the outflow of suffering can be allowed. In addition, the importance of the professional autonomy of nurses to alleviate the anguish of facing the moral conflicts inherent to their practice should be perceived, which demands normative and subjective questions.

The limitations of this study are related to the great emotional mobilization of those who were invited to mainly talk about their anguish working with patients in the process of death. Refusals to participate in this study, due to denial or the unavailability of some nurses, reflect the anxieties exposed in the results discussed here. Their work is silenced by the inability of the professionals to deal with death situations and also by the fear of talking about their lack of control over life. However, it is possible to perceive that the participants of this study provided deep statements, providing a rich approach of the meanings that the work has for each of them. The objectives of clinicalqualitative research are contemplated when these meanings are captured and the phenomena duly explored in a singular way.

Subsequent work to these results may enrich the strategies that favor the listening practices of these care professionals. This is because, although it is possible that anguish permeates the practice of the nurse in the context of death, beside the suffering subject there is always a potency to be developed.

\section{References}

Ariès, P. (2003). História da morte no ocidente. Rio de Janeiro, RJ: Ediouro.

Barbosa, K. K. S., Vieira, K. F. L., Alves, E. R. P., \& Virgínio, N. A. (2012). Sintomas de- 
pressivos e ideação suicida em enfermeiros e médicos da assistência hospitalar. Revista de Enfermagem da UFSM, 2(3), 515-522. doi: $10.5902 / 217976925910$

Barlem, E. D., Lunardi, V. L., Tomaschewski, J. G., Lunardi, G. L., Lunardi, W. D., Filho, \& Schwonke, C. R. G. B. (2013). Moral distress: Challenges for an autonomous nursing professional practice. Revista da Escola de Enfermagem da USP, 47(2), 506-510. doi: 10.1590/ S0080-62342013000200033

Barlem, E. L. D., Lunardi, V. L., Lunardi, G. L., Dalmolin, G. L., \& Tomaschewski, J. G. (2012). Vivência do sofrimento moral na enfermagem: Percepção da enfermeira. Revista da Escola de Enfermagem da USP, 46(3), 681-688. doi: 10.1590/S0080-62342012000300021

Borges, M. S., \& Mendes, N. (2012). Representações de profissionais de saúde sobre a morte e o processo de morrer. Revista Brasileira de Enfermagem, 65(2), 324-331. doi: 10.1590/S003471672012000200019

Carnevale, F. A. (2013). Confronting moral distress in Nursing: Recognizing nurses as moral agentes [Special issue]. Revista Brasileira de Enfermagem, 66, 33-38. doi: 10.1590/S003471672013000700004

Colomé, J. S., \& Oliveira, D. L. L. C. (2012). Educação em saúde: Por quem e para quem? A visão de estudantes de graduação em enfermagem. Texto \& Contexto - Enfermagem, 21(1), 177 184. doi: 10.1590/S0104-07072012000100020

Foucault, M. (2010). A Hermenêutica do sujeito. São Paulo, SP: Martins Fontes.

Foucault, M. (2014). Vigiar e Punir. Rio de Janeiro, SP: Vozes.

Gimenes, G. F. (2013). Uses and meanings of quality of life in the contemporary discourse on health. Trabalho, Educação e Saúde, 11(2), 291-318. doi: 10.1590/S1981-77462013000200003

Manetti, M. L., \& Marziale, M. H. P. (2007). Fatores associados à depressão relacionada ao trabalho de enfermagem. Estudos de Psicologia (Natal), 12(1), 79-85. doi: 10.1590/S1413294X2007000100010

Minayo, M. C. S. (2010). O Desafio do Conhecimento: Pesquisa qualitativa em saúde. São Paulo, SP: Hucitec.
Pelbart, P. (2008). Vida e morte em contexto de dominação biopolítica [Conferência proferida no Ciclo "O Fundamentalismo Contemporâneo em Questão"]. Instituto de Estudos Avançados (IEA) da USP, 20.

Peterson, A. A., \& Carvalho, E. C. (2011). Comunicação terapêutica na Enfermagem: Dificuldades para o cuidar de idosos com câncer. Revista Brasileira de Enfermagem, 64(4), 692-697. doi: 10.1590/S0034-71672011000400010

Poles, K. \& Bousso, R.S. (2006). Compartilhando o processo de morte com a família: A experiência da enfermeira na UTI pediátrica. Revista Latino-Americana de Enfermagem, 14(2), 207-213. doi: 10.1590/S0104-11692006000200009

Rodney, P., Kadyschuck, S., Liaschenko, J., Brown, H., Musto, L., \& Snyder N. (2012). Moral agency: Relational connections and support. In J. L. Storch, P. Rodney, \& R. Starzomski (Eds.), Toward a moral horizon: Nursing ethics for leadership and practice (pp. 160-187). Toronto, Canada: Pearson Education.

Sanches, P. G., \& Carvalho, M. D. B. (2009). Vivência dos enfermeiros de unidade de terapia intensiva frente à morte e o morrer. Revista Gaúcha de Enfermagem, 30(2), 289-296. Retrieved from http://seer.ufrgs.br/index.php/RevistaGauchadeEnfermagem/article/download/3294/6687

Santos, J. L., \& Bueno, S. M. V. (2010). A questão da morte e os profissionais de enfermagem. Revista de Enfermagem da UERJ, 18(3), 484-487. Retrieved from http://www.facenf.uerj.br/v18n3/ v18n3a26.pdf

Santos, Y. S., Jesus, L. C., \& Portella, S. D. C. (2013). A enfermagem e a abordagem da morte infantil: Um estudo de trabalhos qualis A. Revista Enfermagem Contemporânea. 2(1), 112-131. doi: 10.17267/2317-3378rec.v2i1.252

Souza e Souza, L. P., Mota, R. J., Barbosa, R. R., Ribeiro, G. R. C., Oliveira e Silva, C. S., \& Barbosa, D. A. (2013). A morte e o processo de morrer: Sentimentos manifestados por enfermeiros. Enfermería Global, 12(32), 222-229. Retrieved from http://revista.portalcofen.gov.br/repositorio/journals/1/pressrelease/006.pdf

Tschiedel, R. M., \& Monteiro, J. K. (2013). Prazer e sofrimento no trabalho das agentes de segurança penitenciária. Estudos de Psicologia (Natal), 18(3), 527-535. doi: 10.1590/S1413$-294 \times 2013000300013$ 
Turato, E. (2013). Tratado da Metodologia da Pesquisa Clínico-Qualitativa: Construção teórico-espistemológica, discussão comparada e aplicação nas áreas da saúde e humanas. Petrópolis, RJ: Vozes.

Umann, J., Silva, R. M., Benavente, S. B. T., \& Guido, L. A. (2014). O impacto das estratégias de enfrentamento na intensidade de estresse de enfermeiras de hemato-oncologia. Revista Gaúcha de Enfermagem, 35(3), 103-110. doi: 10.1590/1983-1447.2014.03.44642
Vieira. C. A. L., \& Marques, G. H. (2012). Morte, Angústia e Família: Considerações psicanalíticas a partir da Unidade de Terapia Intensiva. Psicanálise \& Barroco em Revista, 10(1), 97108.

Received: 20/07/2016

$1^{\text {st }}$ revision: $11 / 05 / 2017$

Accepted: 17/05/2017 